\title{
Transmission failure of parasites (Digenea) in sites colonized by the recently introduced invasive alga Caulerpa taxifolia
}

\author{
Pierre Bartoli*, Charles-François Boudouresque \\ UMR 6540 CNRS, Dimar, Centre d'Océanologie de Marseille, Campus Universitaire de Luminy, Case 901, \\ F-13288 Marseille cédex 09, France
}

\begin{abstract}
The recently introduced invasive tropical seaweed Caulerpa taxifolia has by now invaded large areas of the western Mediterranean coast between Nice (France) and Imperia (Italy). The labrid fish Symphodus ocellatus, which usually inhabits Posidonia oceanica meadows or lives among photophilic algae growing on rocky substrates, is also present in areas which are thickly covered with $C$. taxifolia. This fish is territorial and sedentary, and its life span is never more than $3 \mathrm{yr}$. Since C. taxifolia has been present since 1987 in the areas studied, the $S$. ocellatus individuals living there can be assumed to have probably spent their whole post-larval lives in the vicinuty of the seaweed. At the colonized sites, the mvertebrate benthic prey of $S$. ocellatus have undergone both quantitative and qualitative changes. The effects of these changes on the transmission of parasites were studied using the digeneans of the digestive tract of $S$. ocellatus as a model. At the control sites, 6 digenean species were identified: Helicometra fasciata, Macvicaria alacris, Proctoeces maculatus, Holorchis pycnoporus, Lecithaster stellatus and Genitocotyle mediterranea (cumulative prevalence of all species $=46.3 \%$; cumulative abundance of all species $=0.95$ ). At the sites colonized by $C$. taxifolia, only 2 digenean species were present: $H$. fasciata and $L$. stellatus (cumulative prevalence $=1.5 \%$; cumulative abundance $=$ 0.02 ). Among the possible reasons explaining the nearly complete absence of digeneans parasitizing $S$. ocellatus, the rarefaction of intermediate hosts in the invaded areas can probably be ruled out, at least in the case of 2 dıgenean species. Secondary metabolites (caulerpenyne and other terpenes) synthesized by $C$. taxifolla, and then released into the environment or transmmitted along the food web, might be responsible for the near-complete disappearance of the digeneans of $S$. ocellatus
\end{abstract}

KEY WORDS: Caulerpa taxifolia. Parasites Life cycles. Digeneans Transmission Symphodus ocel latus. Mediterranean

\section{INTRODUCTION}

Caulerpa taxifolia (Vahl) C. Agardh is a seaweed (Ulvophyceae, Caulerpales) which is widespread in circumtropical areas. A cold-water-resistant strain originating from aquaria (Caye et al. 1996) has been recently introduced along the northern littoral areas of the Western Mediterranean. It is now spreading rapidly between Nice (Alpes-Maritimes, France) and Imperia (Italy) and a large coastal area has already been invaded (Belsher et al. 1994, Belsher \& Meinesz 1995. Meinesz et al. 1995). As the result of this inva-

\footnotetext{
•E-mail: plerre.bartoli@ceram.u-3mrs.fr
}

sion, the infralittoral communities have changed drastically (Meinesz \& Hesse 1991, Boudouresque et al. 1992, Meinesz et al. 1993). Several authors have described the highly conspicuous floristic changes which have occurred in invaded areas (Verlaque \& Fritayre 1994, Villèle \& Verlaque 1995). The first results to be published on ichthyofauna have shown that the structure of the population of most species (with the exception of Symphodus spp.) has changed and that the number of individuals and the biomass have declined significantly (Francour et al. 1994, 1995, Harmelin-Vivien et al. 1996). As far as invertebrates are concerned, the changes are less conspicuous. It is mainly the numbers of the polychaeta and mollusc individuals which have declined and, to a lesser 
extent, those of the crustaceans (Bellan-Santini et al 1994, 1996. Bellan-Santini 1995)

The labrid fush Symphodus ocellatus (Forsskál. 17 $\bar{f}$ j) is one of the usual inhabitants of the Posidonia oceanica (Linnaeus) Delile meadows and of the meadows of photophllic algae living on hard substrates (HarmelinVivien 1982, Lejeune 1985, Nichel et al. 1987) This teleost is also present in the Caulerpa taxifolia meadows at sites where this algal meadow has replaced the 2 previous communities (mean abundance: 3 to 5 individuals per $10 \mathrm{~m}^{2}$ ): the mean abundances of the adults did not differ significantly between the control sites and sites colonized by C Laxifolla \{Francour et al 1995, Harmelın-Vivien et al. 1996) The life span of this terrıtorlal, sedentary labrid is never more than 3 yr (Lejeune 1985) Since C. taxifolia is present in some areas which have been studied since 1987 (eastern coast of Cap Martin) and 1990 (Cap d'All) (Meinesz et al. 1993), it can be assumed that the $S$ ocellatus individuals living there have spent all of thelr post-larval lives in $C$ taxifolia

The prey of Symphodus ocellatus consists of benthic inverteblates (Bell \& I Iarmelin-Vivien 1983, Khoury 1984) Since the invertebrate benthic fauna has changed from both the qualitative and quantitative points of view, the question arises as to what has happened to the digenean fauna parasitizing this teleost. In fact, digenetıc trematoda have an heteroxenic life cycle In a life cycle of this kind, the first host is always

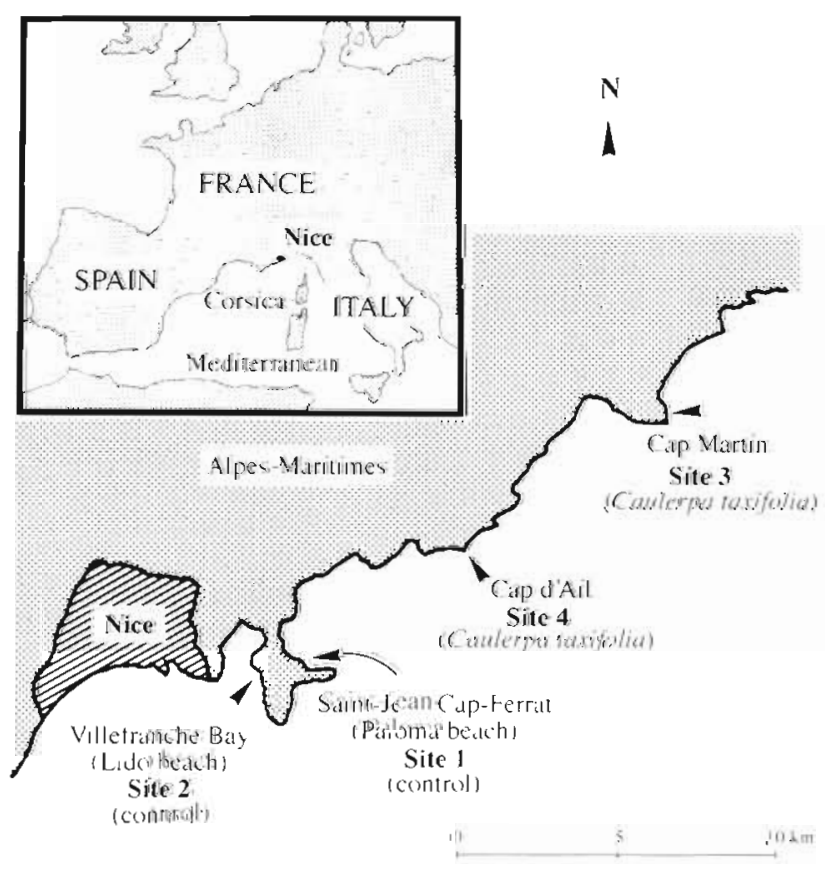

Fig. 1. Sites studied in spring and summer 1995. Sites 1 and 2 control sites not yet invaded by Caulerpa taxifolia. Sites 3 and 4: sites highly colonized by C. taxifolia a mollusc, while the second intermediate hosts can be any group of invertebrates.

With a view to answering this question, we carried out qualitative and quantitative comparisons of the digenean fauna of Symphodus ocellatus living, on the one hand, in an indigenous algal community not yet invaded by Caulerpa taxifolia and, on the other hand, in a dense C. taxifolia meadow.

\section{MATERIALS AND METHODS}

For this study, 4 sites along the Alpes-Maritimes littoral (near Nice, France, western Mediterranean) were selected (Fig 1). The 2 control sites, which have not yet been invaded by Caulerpa taxifolia, are inhabited by a community malnly consisting of indigeneous photophilic algae living on hard substrates. These algae include Haloptens scoparia (Linnaeus) Sauvageau, Haloptens filicina (Grateloup) Kützing, Corallina elongata Ellis \& Solander, Haliptilon virgatum (Zanardini) Garbary \& Johansen, Rhodymenia ardissonei Feldmann., and Dictyota fasciola (Roth) Lamouroux. The first control site (Site 1) was located at Saint-Jean-CapFerrat (Paloma beach); sampling was performed there at depths of between 2 and $6 \mathrm{~m}$. The second control site (Site 2) was located in Villefranche Bay (Lido beach); sampling was performed there at depths of between 1 and $5 \mathrm{~m}$.

The other 2 sampling sites were located in areas whuch are completely overgrown by Caulerpa taxifolla, but which were previously occupied by the same indigeneous photophilic algae as those present at the control sites. Sampling was performed at the invaded sites at depths of between 2 and $6 \mathrm{~m}$ along the eastern coast of Cap Martun (Site 3), where C. taxifolia has been present since 1987, and between 7 and $10 \mathrm{~m}$ at Cap d'All (Site 4), where C. taxifolia has been present since 1990 (Mennesz et al. 1993).

At all these sites, live individuals of Symphodus ocellatus were caught by scuba divers using a hand net in late spring 1995 (Sites 1 and 3) and in late summer 1995 (Sites 1, 2, 3 and 4) Since digeneans settle in this fish host only when the host has reached a mean total length (TL) of more than $65 \mathrm{~cm}$ (Bartoli \& Riutort 1994), only adult individuals with at least this TL were caught. When scuba divers approach S. ocellatus, the fish react by remaining motionless in the vegetation, so that they are easy to capture Our samples were therefore pertectly representative, and were not biased by the teleost's ability to escape. When the fish were caught, they were kept alıve in an aquarium for $4 \mathrm{~h}$ at the most and then killed and autopsied. Their sex and social status were determuned based on their behaviour and color patterns Their total length (TL) was measured in mm. 
In this study, we focused on the community of intestinal digeneans (adult stages) as well as on the encysted metacercariae (larval stages) encapsulated in the mesentery. Each digenea was identified from stained permanent preparations. Two parasitological indexes defined by Nargolis et al. (1982) were used: the 'prevalence', expressed as a percentage (number of individuals of a host species infected with a particular parasite species/number of hosts examined), and the 'abundance' [total number of individuals of a particular parasite species in a sample of hosts/total number of individuals of the host species (infected + uninfected) in the sample]. Since all the digenean adults, irrespective of species, were taken into account, we used the terms 'cumulative prevalence' (of all species) and 'cumulative abundance' (of all species). The statistical tests used were based on Sherrer (1984).

\section{RESULTS}

At autopsy, the digestive tracts of 134 Symphodus ocellatus captured at the control sites (Sites 1 and 2) during the 2 seasons showed the presence of 6 digenean species (Table 1). Three of them were present at the end of the spring as well as at the end of the summer: Helicometra fasciata (Rudolphi, 1819) (Opecoelidae), Macvicaria alacris (Looss, 1901) (Opecoelidae) and Proctoeces maculatus (Looss, 1901) (Fellodistomidae). One species was detected only at the end of the spring Holorchis pycnoporus Stossich, 1901 (Lepocreadiidae). The remaining 2 species were present only at the end of the summer: Lecithaster stellatus Looss,
1907 (Hemiuridae) and Genitocotyle mediterranea Bartoli, Gibson \& Riutort, 1994 (Opecoelidae). In all these adult species combined, the cumulative prevalence (Fig 2) as well as the cumulative abundance at each control site and in each season were very high (Table 2). Upon combining the control sites and seasons, the mean cumulative prevalence of the adult parasitism amounted to $46.26 \%$ and the mean cumulative abundance to 0.95 . In addition, numerous encysted metacercariae of an unidentified hemiuroid species were found encapsulated in the mesentery of the hosts (prevalence $=100 \%$; abundance $>10$ )

At autopsy, 131 Symphodus ocellatus caught in the Caulerpa taxifolia meadows (Sites 3 and 4) showed the

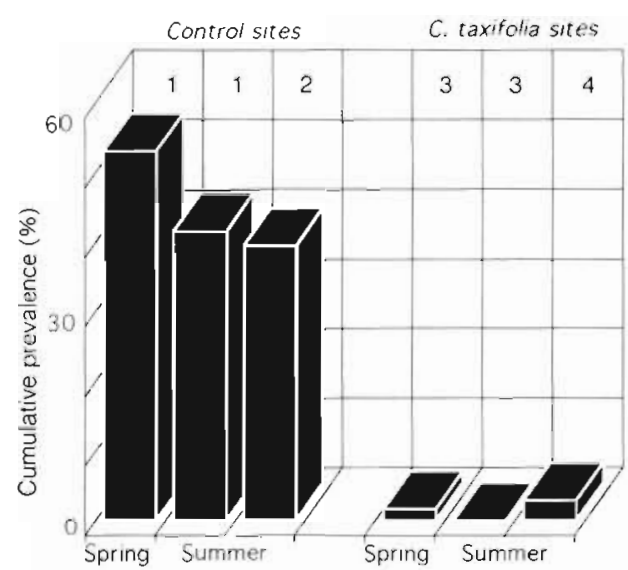

Fig. 2. Cumulative prevalence of adult digenean parasites in the digestive tract of Symphodus ocellatus at the end of spring and at the end of summer 1995 at the control sites ( 1 and 2) and at sites highly colonized by Caulerpa taxifoha ( 3 and 4 )

Table 1 Parasitological indice (P: prevalence; A: abundance) of Symphodus ocellatus at the 4 sampling sites and during 2 seasons in 1995. HEFA: Helicometra fasciata; MAAL: Macvicaria alacris; PRMA: Proctoeces maculatus; HOPY; Holorchis pycnoporus; LEST: Lecithaster stellatus; GEME: Genitocotyle mediterranea; n: no of autopsied fish

\begin{tabular}{|c|c|c|c|c|c|c|c|c|}
\hline & \multicolumn{4}{|c|}{ Control sites } & \multicolumn{4}{|c|}{ Sites colonized by Caulerpa taxifolla } \\
\hline & \multicolumn{2}{|c|}{ Site 1} & \multicolumn{2}{|c|}{ Site 2} & \multicolumn{2}{|c|}{ Site 3} & \multicolumn{2}{|c|}{ Site 4} \\
\hline & $\mathrm{P}$ & $\mathrm{A}$ & $\mathrm{P}$ & A & $\mathrm{P}$ & A & $\mathrm{P}$ & A \\
\hline Spring 1995 & \multicolumn{2}{|c|}{$\mathrm{n} \equiv 62$} & \multicolumn{2}{|c|}{$\mathrm{n}=0$} & \multicolumn{2}{|c|}{$\mathrm{n}=60$} & \multicolumn{2}{|c|}{$\mathrm{n}=0$} \\
\hline HEFA & 35.50 & 0.68 & & & 1.66 & 0.03 & & \\
\hline MAAL & 20.96 & 0.32 & & & 0 & 0 & & \\
\hline PRMA & 3.22 & 0.08 & & & 0 & 0 & & \\
\hline HOPY & 4.80 & 0.10 & & & 0 & 0 & & \\
\hline LEST & 0 & 0 & & & 0 & 0 & & \\
\hline GEME & 0 & 0 & & & 0 & 0 & & \\
\hline Summer 1995 & \multicolumn{2}{|c|}{$n=24$} & \multicolumn{2}{|c|}{$\mathrm{n}=48$} & \multicolumn{2}{|c|}{$\mathrm{n}=37$} & \multicolumn{2}{|c|}{$\mathrm{n}=34$} \\
\hline HEFA & 12.50 & 0.17 & 8.30 & 0.08 & 0 & 0 & 0 & 0 \\
\hline MAAL & 8.30 & 0.12 & 8.30 & 0.08 & 0 & 0 & 0 & 0 \\
\hline PRMA & 4.16 & 0.04 & 0 & 0 & 0 & 0 & 0 & 0 \\
\hline HOPY & 0 & 0 & 0 & 0 & 0 & 0 & 0 & 0 \\
\hline LEST & 20.80 & 0.29 & 22.90 & 0.58 & 0 & 0 & 2.94 & 0.03 \\
\hline GEME & 0 & 0 & 2.10 & 0.04 & 0 & 0 & 0 & 0 \\
\hline
\end{tabular}


Table 2. Cumulative prevalence $(P, \%)$ and cumulative abundance $(A$, mean $\pm S D$ ) of adult digenean parasites of Symphodus ocellatus late in spring and late in summer 1995, at control sites ( 1 and 2 ) and at sites highly colonized by Caulerpa taxifolia (3 and 4). S: number of digenean adult species; n: no. of autopsied fish

\begin{tabular}{|c|c|c|c|c|}
\hline & \multicolumn{2}{|c|}{ Control sites } & \multicolumn{2}{|c|}{$\begin{array}{l}\text { Sites colonized by } \\
\text { C. taxifolia }\end{array}$} \\
\hline & 1 & 2 & 3 & 4 \\
\hline \multicolumn{5}{|c|}{ Spring 1995} \\
\hline$P$ & \multicolumn{2}{|l|}{$53.22 \%$} & \multicolumn{2}{|l|}{$1.66 \%$} \\
\hline A & \multicolumn{2}{|l|}{$1.18 \pm 1.78$} & \multicolumn{2}{|c|}{$0.03 \pm 0.26$} \\
\hline S & \multicolumn{2}{|l|}{4} & \multicolumn{2}{|l|}{1} \\
\hline $\mathrm{n}$ & \multicolumn{2}{|l|}{62} & \multicolumn{2}{|l|}{60} \\
\hline \multicolumn{5}{|c|}{ Summer 1995} \\
\hline $\mathrm{P}$ & $41.66 \%$ & $39.58 \%$ & $0 \%$ & $2.94 \%$ \\
\hline A & $0.63 \pm 0.87$ & $0.81 \pm 1.99$ & 0.00 & $0.03 \pm 0.17$ \\
\hline S & 4 & 4 & 0 & 1 \\
\hline$n$ & 24 & 48 & 37 & 34 \\
\hline \multicolumn{5}{|c|}{ Sites and seasons combined } \\
\hline $\mathrm{P}$ & \multicolumn{2}{|c|}{$46.26 \%$} & \multicolumn{2}{|c|}{$1.52 \%$} \\
\hline A & \multicolumn{2}{|c|}{$0.95 \pm 1.74$} & \multicolumn{2}{|c|}{$0.02 \pm 0.19$} \\
\hline $\mathrm{S}$ & \multicolumn{2}{|c|}{6} & \multicolumn{2}{|c|}{2} \\
\hline $\mathrm{n}$ & \multicolumn{2}{|c|}{134} & \multicolumn{2}{|c|}{131} \\
\hline
\end{tabular}

presence of only 2 digeneans (Table 1): Helicometra fasciata (in 1 fish only at the end of the spring; prevalence $=1.66 \%$ ) and Lecithaster stellatus (in 1 fish only at the end of the summer; prevalence $=2.94 \%$ ) (Fig. 2). Upon combining these 2 sites and seasons, the mean cumulative prevalence of the adult parasites amounted to $1.52 \%$ and the mean cumulative abundance was 0.02 (Table 2). In less than $10 \%$ of the fish, the mesentery harboured some very rare metacercariae of the previous undetermined hemiuroid species.

\section{DISCUSSION}

Only 1 study has been carried out to date on the digeneans which parasitize Symphodus ocellatus; it was performed at sites located on the western coast of Corsica (Western Mediterranean) (Bartoli \& Riutort 1994), where in a sample consisting of 258 S. ocellatus, only 3 digenean species were detected: Macvicaria alacris, Genitocotyle mediterranea and Lecithaster stellatus (cumulative prevalence $=28.30 \%$; cumulative abundance $=0.99$ ). In the $S$. ocellatus of Corsica, no Helicometra fasciata, Proctoeces maculatus or Holorchis pycnoporus were present.

At the control sites in the present study (Sites 1 and 2), digenean parasites of Symphodus ocellatus can therefore be said to rate high in terms of both their prevalence and their abundance.
Upon combining all the sites (control and invaded) and seasons (spring and summer), we observed heterogeneity in both the cumulative prevalence ( $G$-test for contingency tables; $\mathrm{H}_{0}$ : homogeneous samples; rejected: $G_{C}=88.7, v=5, \alpha=0.005$ ) and the cumulative abundance (Kruskal-Wallis test; $\mathrm{H}_{0}$ : abundance is the same; rejected: $\alpha<0.001$ ).

Upon applying these tests to the combined control site samples and to the combined samples for sites invaded by Caulerpa taxifolia, results were found to be homogeneous. At the control sites, the values obtained at the end of the spring and at the end of the summer did not differ for either the cumulative prevalence $(G$ test for contingency tables; $\mathrm{H}_{0}$ : homogeneous samples; not rejected: $G_{C}=2.1, v=2$ ) or the cumulative abundance (Kruskal-Wallis test; $\mathrm{H}_{0}$ : abundance is the same; not rejected: $H=1.6, v=2$ ). Nor were any differences observed at the sites invaded by $C$. taxifolia for the cumulative prevalences ( $G$-test for contingency tables; $G_{\mathrm{C}}=3.5, v=2$ ) or the cumulative abundances (Kruskal-Wallis test: $H=1.0, v=2$ ).

Significant differences therefore existed between the samples consisting of indigeneous communities (Sites 1 and 2) and those from areas invaded by Caulerpa taxifolia (Sites 3 and 4). To account for these differences, 3 hypotheses can be proposed. which are not necessarily mutually exclusive.

(1) The 7 digenean species $(6$ adult and 1 metacercaria species) were practically absent in the Symphodus ocellatus living in a Caulerpa taxifolia meadow, possibly because of the rarefaction or the disappearance from this community of an intermediate host involved in the life cycle of each digenean. Authors of studies conducted on freshwater as well as on marine communities have attributed observed changes in the prevalence of the parasites to the decrease in the number of intermediate hosts or to the fact that they disappear when exposed to urban or industrial pollutants (Overstreet \& Howse 1977, Burn 1980, Valtonen et al. 1987, Overstreet 1988, Sulgostowska 1988, Mackenzie et al. 1995).

There are several possible ways of accounting for the rarefaction or the disappearence of intermediate hosts and the resulting change in the diet of Symphodus ocellatus: (1.1) Caulerpa taxifolia does not constitute a suitable habitat for intermediate hosts (e.g. absence of food resources, change in abiotic characteristics of the habitat); (1.2) effects of toxic secondary metabolites synthesized by this alga (see below: 'second hypothesis').

In our study, if the life cycle of each of these 6 digenean adult species parasitizing Symphodus ocellatus had been previously elucidated, it might have been possible to deduce which species have become rarefied or have disappeared in this new Caulerpa taxifo- 
lia community. Unfortunately, the life cycle has been described in only 2 of these 6 species:

Holorchis pycnoporus. First intermediate host: Barleeia rubra (Adams, 1795) (Prosobranchia, Rissoidae); second intermediate hosts: Barleeia rubra and some small lamellibranchs such as Parvicardium papillosum (Poli) (Cardiidae) (Bartoli \& Prévot 1979).

Proctoeces maculatus. First intermediate host: Mytilus galloprovincialis Lamarck (Bivalvia, Mytilidae); second intermediate hosts: Mytilus galloprovincialis, Rissoa auriscalpium (Linnaeus) (Prosobranchia, Rissoidae) and some species of nereid polychaetes (Prévot 1965, Martinez 1972)

The life cycles of the 4 other species, Helicometra fasciata, Macvicaria alacris, Lecithaster stellatus and Genitocotyle mediterranea, are still unknown. Nevertheless, considering taxonomically closely related species, the first host is definitely molluscs. Lecithaster stellatus may have a prosobranch or an opisthobranch as first intermediate host and copepods as second hosts; the 3 remaining species, all belonging to Opecoelidae, have a prosobranch as first intermediate host and probably crustaceans as second hosts.

As far as identified intermediate hosts are concerned (namely Barleeia rubra and Mytilus galloprovincialis), P. M. Arnaud \& D. Bellan-Santini (pers. comm.), who have analysed the invertebrate fauna at the stations studied here, did not note any differences between the control sites and those colonized by Caulerpa taxifolia as regards the number of individuals. The rarefaction of Holorchis pycnoporus and Proctoeces maculatus of Symphodus ocellatus living in the C. taxifolia meadow must therefore have occurred for some reason other than one involving the rarefaction of intermediate hosts.

(2) It is possible that some toxic substances present in the environment may directly affect the free larval infective stages of the digeneans (miracidia, cercariae). Siddall \& des Clers (1994) reported, for example, that exposure to a low concentration of sewage sludge in seawater significantly reduced the viability of the miracidia and cercariae of the digenean flatfish parasite Zoogonoides viviparus. These sewage sludges contained traces of a variety of heavy metals, such as mercury, lead, cadmium, copper, etc. (see also Abd Allah et al. 1996 for freshwater). When several heavy metals of this kind are combined, they may have synergistic effects on the survival of parasites (Siddall \& des Clers 1994). The pattern of transmission of the larvae to the first mollusc host and to the invertebrate second intermediate hosts is thus transformed (MacKenzie et al. 1995).

Some toxic metabolites such as caulerpenyne or other terpenes have been identified in Caulerpa taxifolia (see Guerriero et al. 1992, 1993). A large amount of caulerpenyne can be synthesized by this weed, amounting to up to $13 \%$ of its dryweight in summer (Valls et al. 1994a, b, Amade et al. 1996). The toxicity of C. taxifolia is at a maximum from June to December (Lemée et al. 1993). Ferrer et al. (1995) have indirectly demonstrated that toxic substances are released by $C$. taxifolia cultures. The toxic substances are usually released into the environment during the warm season (from the end of the spring to the end of the fall).

The terpenes released by Caulerpa taxifolia have been found to have toxic effects on various species of free ciliates. Dosages lower than $1 \mathrm{\mu g} \mathrm{m}^{-1}$ prove to be lethal to $100 \%$ of individuals of some strains (Dini et al. 1994). Furthermore, dosages as low as $1.5 \mu \mathrm{g} \mathrm{ml}^{-1}$ of caulerpenyne, the most abundant terpene produced by C. taxifolia, so deeply affect the behaviour (e.g. movement, velocity) of the ciliate Euplotes crassus that the organism loses the ability to escape from the source of the caulerpenyne, thus becoming doomed to a quick death (Dini et al. 1996). These toxic substances may likewise directly affect the life span of the digenean larvae, as well as changing their behaviour and their ability to meet their target host, and they may possibly block digenean access to the second intermediate host. As a result, the transfer from one host to another might become difficult, especially because the cercarial shedding period (from the end of spring to the end of fall) and the production and release of toxic substances by $C$. taxifolia occur at the same time.

In all the previous studies in which the harmful effects of polluting substances on parasite transmission have been pointed out, the pollution incriminated has been anthropogenic (urban or industrial pollution, paper and pulp plant effluent, sewage and pesticides coal mud, petroleum wastes and high-iron effluent PCBs, heavy metals, etc.) (Mackenzie et al. 1976, 1995 Holliman \& Esham 1977, Overstreet \& Howse 1977 Burn 1980, Anikieva 1982, Evans 1982a, b, Overstreet 1988, Sidall \& des Clers 1994, Abd Allah et al. 1996). In the present study, the toxic substances involved are not of anthropogenic but biotic origin, since they are produced by a plant within the community, namely the newly introduced species Caulerpa taxifolia.

(3) Invertebrate intermediate hosts living among Caulerpa taxifolia may ingest this alga, and may consequently accumulate the alga's metabolites in their own tissues. The settlement of the parasites in the host (rediae or sporocysts in the first host, metacercariae in the second intermediate host) might thus become impossible. On the other hand, when the invertebrate prey which have eaten $C$. taxifolia are ingested by Symphodus ocellatus (definitive host), the metabolites they contain may be present or may accumulate in the digestive tract of the fish. One cannot rule out the hypothesis that these toxic substances may block the 
recruitment and settlement of larvae and thus prevent them from invading their definitive hosts.

Similar results have been published by several authors, but the effects described have again always been due to substances of anthropogenic origin (MacKenzie et al. 1995). For example, crude oil anaesthetizes and then eliminates nematode parasites from the digestive tract of fish (Kiceniuk \& Khan 1983). These authors suggested that this elimination may have resulted from a direct toxic action on the parasites along with an indirect action on their digestive environment.

\section{CONCLUSION}

The results of this study show that the fish Symphodus ocellatus living in meadows of the recently introduced Caulerpa taxifolia are hardly parasitized at all, whereas those living in communities where the indigeneous algae are still predominant are infected with an abundant community of digeneans. The majority of the previous investigations on $C$. laxifolia meadows have shown the existence of a tendency for the biodiversity to decrease at these sites. Our results are consistent with this tendency.

Although the exact reasons for these changes have not yet been identified, it seems likely that secondary metabolites synthesized by Caulerpa taxifolia and then released into the environment or transmitted along the food web might be responsible for the nearly complete disappearance of the digeneans of Symphodus ocellatus. Laboratory experiments with cercariae of several digenean species will be performed in order to confirm the field results. Moreover, should C. taxifolia continue to spread, our results on the digenean fauna at the present control sites will become even more useful as control data, when these sites are also invaded by this alga.

The destruction of parasites by exogenic substances of anthropogenic origin is a well-known process (Mackenzie et al. 1995). To our knowledge, however, no previous studies have dealt with effects of natural. metabolites on these organisms.

The diversity of digeneans appears to be a good index of the health of benthic communities. Bartoli (1987, 1990) has reported that, in areas where the human impact is weak, as in the Natural Reserve of Scandola (Corsica, western Mediterranean), the digenean parasitofauna generally includes a large number of species as well as of individuals. In addition, an index of this kind based upon the digenean diversity can be very sensitive. Actually, it is worth noting that, although the toxic effects of the proliferating Caulerpa taxifolia on the various faunistic components are sig- nificant (Bellan-Santini et al. 1994, Francour et al. 1995), their amplitude is generally smaller than that of the effects described in this study on the digenean fauna of Symphodus ocellatus.

Acknowledgements. This research work was performed in the framework of the following programme: European Union (DG 11), French Ministere de l'Environnement and GIS Posidonie (Control of the expansion of the alga Caulerpa taxifolia introduced into the Mediterranean). The authors are indebted to J. J. Riutort for field assistance, Prof. A. Meinesz for laboratory faciluties and anonymous reviewers for pertinent suggestions and improvement of the manuscript.

\section{LITERATURE CITED}

Abd Allah AT, Wanas MQ. Thompson SN (1996) The effects of lead, cadmium, and mercury on the mortality and infectivity of Schistosoma mansoni cercariae. J Parasitol 82: $1024-1020$

Amade P, Lemee R, Pesando D, Valls R, Meinesz A (1996) Variations de la production de caulerpenyne dans Caulerpa taxifolia de Méditerranée. In: Ribera MA, Ballesterus E, Boudouresque CF, Gomez A, Gravez V (eds) Second International Workshop on Caulerpa taxifolia. Publicacions Universitat Barcelona, p 223-231

Anikieva LV (1982) The influence of waste waters of Segezhsk paper and pulp plant on the helminth fauna of fish in Laka Vygozero. In: Ekologiya paraziti-cheskikh organizmov $v$ biogeotsenozahk severa. Karel'skii Filial Akademii Nauk SSSR, Institut Biologii, Petrozavodsk, USSR, $p 72-83$

Bartoli P (1987) Les Trématodes digénétiques parasites des poissons Sparidés de la Réserve Naturelle de Scandola. Trav Scı Parc Natl Rég Rés Natls Corse 10:1-158

Bartoli P (1990) Distomatoses des poissons Téléosteens de l'herbier de Posidonies de la Réserve Naturelle de Scandola. I. Les Trématodes digénétiques de la Rascasse brune, Scorpaena porcus. Trav Sci Parc Natl Rég Rés Natls Corse 26:1-24

Bartoli P. Prévot G (1979) Le cycle biologique de Holorchis pycnoporus M. Stossich 1901 (Trematoda, Lepocreadiidae). Z Parasitenkd 58:73-90

Bartolı P, Riutort JJ (1994) Composants, structure et évolution de la guilde des Digènes intestinaux parasites de Symphodus ocellatus sur la fucude maritime du Parc Naturel Régional de Corse. Trav Sci Parc Natl Rég Rés Natls Corse $46: 41-70$

Bell JD, Harlelin-Vivien M (1983) Fish fauna of French Mediterranean Posidonia oceanica seagrass meadows. 2. Feedings habits. Téthys 11:1-14

Bellan-Santini D (1995) Faune d'invertébrés du peuplement à Caulerpa taxifolia. Données préliminaires pour les côtes de Provence (Méditerranée nord-occidentale). Biol Mar Medit 2:635-643

Bellan-Santin. D, Arnaud PM, Bellan G, Verlaque M (1994) Résultats préluminaires sur la faune d'invertébrés du peuplement à Caulerpa taxifolia des côtes de Provence (Méditerranée nord-occidentale). In: Boudouresque CF, Meinesz A. Gravez V (eds) First International Workshop on Caulerpa taxifolia. GIS Posidonie Publications, Marseille, p 365-369

Bellan-Santini D, Arnaud PM, Bellan G, Verlaque M (1996) 
The influence of the introduced tropical alga Caulerpa taxifolia, on the biodiversity of the Mediterranean marine biota. J Mar Biol Assoc UK 76:235-237

Belsher T, Meinesz A (1995) Deep water dispersal of the tropical alga Caulerpa taxifolia introduced into the Mediterranean. Aquat Bot 51:163-169

Belsher T, Youenou G, Dimeet J, Raillard JM, Bertrand S, Mereau N (1994) Cartographie et évolution de Caulerpa taxifolia (Alpes maritimes et Principauté de Monaco; année 1992). In: Boudouresque CF, Meinesz A, Gravez V (eds) First International Workshop on Caulerpa taxifolia. GIS Posidonie Publications, Marseille, p 147-154

Boudouresque CF, Meinesz A, Verlaque M, Knoepffler-Peguy M (1992) The expansion of the tropical alga Caulerpa taxifolia in the Mediterranean. Cryptogam Algol 13:144-145

Burn PR (1980) Pollution effects on fish parasites. Coast Ocean Pollut Assessm News 1:3-4

Caye $G$, Chambet P, Delahaye L, Meinesz A, Pietkiewicz D, Ryder K (1996) Différences entre Caulerpa taxifolia de Méditerranée et $C$. taxifolia des mers tropicales. In: Ribera MA, Ballesteros E, Boudouresque CF, Gomez A, Gravez V (eds) Second International Workshop on Caulerpa taxifolia. Publicacions Universitat Barcelona, $\mathrm{p}$ 171-176

Dini F, Capovani C, Durante M, Pighini M, Ricci N, Tomei A, Pietra F (1996) Principles of operation of the toxic system of Caulerpa taxifolia that undertook a genetically conditioned adaptation to the Mediterranean Sea. In: Ribera MA, Ballesteros E, Boudouresque CF, Gomez A, Gravez V (eds) Second International Workshop on Caulerpa taxifolia. Publicacions Universitat Barcelona, p 247-254

Dini F, Rosati G, Erra F, Verni F, Pietra F (1994) The environmental toxicity of secondary metabolites produced by the Mediterrannan-adapted seaweed Caulerpa taxifolia using marine ciliate protists as a model. In: Boudouresque CF, Meinesz A, Gravez V (eds) First International Workshop on Caulerpa taxifolia. GIS Posidonie Publications, Marseille, p 203-207

Evans NA (1982a) Effects of copper and zinc on the life cycle of Notocotylus attenuatus (Digenea: Notocotylidae). Int $J$ Parasitol 12:363-369

Evans NA (1982b) Effect of copper and zinc upon the survival and infectivity of Echinoparyphium recurvatum cercariae. Parasitology 85:295-303

Ferrer E, Gomez Garreta A, Ribera MA (1995) Effet de Caulerpa taxifolia sur la productivité de deux macrophytes méditerranéennes. Rapp PV Reun Comm Int Explor Sci Mer Médit 34:28

Francour P, Harmelin-Vivien M, Harmelin JG, Duclerc J (1994) Evolution des peuplements de poissons entre 1992 et 1993, dans les zones colonisées par Caulerpa taxifolia à Menton. In: Boudouresque CF, Meinesz A, Gravez V (eds) First International Workshop on Caulerpa taxifolia. GIS Posidonie Publications, Marseille, p 379-384

Francour P, Harmelin-Vivien M. Harmelin JG, Duclerc J (1995) Impact of Caulerpa taxifolia colonization on the littoral ichthyofauna of North-Western Mediterranean sea: preliminary results. Hydrobılogia 300/301:345-353

Guerriero A, Marchetti F, D'Ambrosio M, Senesi S, Dini F, Pietra $F$ (1993) New ecotoxicologically and biogenetically relevant terpenes of the tropical green alga Caulerpa taxIfolia which is invading the Mediterranean. Helv Chım Acta 76:855-864

Guerriero A, Meinesz A, D'A mbrosio M, Pietra F (1992) Isolation of toxic and potentially toxic sesqui- and monoterpenes from the tropical green seaweed Caulerpa taxifola which has invaded the region of Cap Martin and Monaco. Hely Chim Acta 75:689-695
Harmelin-Vivien M (1982) Ichthyofaune des herbiers de Posidonies du Parc-National de Port-Cros: I. Composition et variations spatio-temporelles. Trav Sci Parc Natl Port-Cros Fr 8:69-92

Harmelin-Vivien M, Harmelın JG, Francour P (1996) A 3-year study of the littoral fish fauna of sites colonized by Caulerpa taxifolia in the N.W. Mediterranean (Menton, France). In: Ribera MA, Ballesteros E, Boudouresque CF Gomez A, Gravez V (eds) Second International Workshop on Caulerpa taxifolia. Publicacions Universitat Barcelona, p 391-397

Holliman RB, Esham LP (1977) Toxicty of cadmium to Schistosoma mansoni cercariae: effects on viability and developmental ability within white mice. Hydrobiologia 56 $81-88$

Khoury C (1984) Ethologies alimentaires de quelques espèces de poissons de l'herbier de Posidonies du Parc National de Port-Cros. In: Boudouresque CF, Jeudy de Grissac A, Olivier J (eds) International Workshop on Posidonia oceanica Beds. CIS Posidonie Publications, Marseille, p 335-347

Kiceniuk J, Khan RA (1983) Toxicology of chronic crude oil exposure: sublethal effects on aquatic organisms. In: Nraigu JO (ed) Aquatic toxicology. J Wiley, New York, p $425-536$

Lejeune P (1985) Le comportement social des Labridés Méditerranéens. Cah Ethol Appl 5:1-208

Lemée R, Pesando D, Durand-Clément M. Dubreuil A, Meinesz A, Guerrero A, Pietra F (1993) Preliminary survey of toxicity of the green alga Caulerpa taxifolia introduced into the Mediterranean. J Appl Phycol 5:485-493

Mackenzie K, Mcvicar AH, Waddell IF (1976) Some parasites of plaice Pleuronectes platessa L. in three different farm environments. Scott Fish Res Rep 4:1-14

Mackenzie K, Williams HH, Williams B, Mcvicar AH, Siddall $R$ (1995) Parasites as indicators of water quality and the potential use of helminth transmission in marine pollution studies. Adv Parasitol 35:85-144

Margolis L, Esch GW, Holmes JC, Kuris AM, Schad GA (1982) The use of ecological terms in parasitology (report of an ad hoc committee of the American Society of Parasitologists). J Parasitol 68:131-133

Martinez JC (1972) Recherches sur quelques stades larvaires de Digenes parasites de Mytilus galloprovincialis Lmk. Thèse, Université des Sciences et Techniques du Languedoc

Meinesz A. Hesse B (1991) Introduction et invasion de l'algue tropicale Caulerpa taxifolia en Méditerranée nord-occidentale. Oceanol Acta 14:415-426

Meinesz A, Vaugelas de J. Hesse B, Mari X. (1993) Spread of the introduced tropical green alga Caulerpa taxifolia in northern Mediterranean waters. J Appl Phycol 5:141-147

Meinesz A, Vaugelas de J, Cottalorda JM, Benichou L, Blachier J, Caye G, Chambet P. Delahaye L, Febvre M, Garin S, Komatsu T, Lemée R, Mari X, Molenaar H, Perney L, Pietkiewicz D (1995) Suivi de l'invasion de l'algue tropicale Caulerpa taxifolia devant les côtes françaises de la Méditerranée. Situation au 31 Décembre 1994. Université de Nice Sophia-Antıpolis: 1-122

Michel C, Lejeune P, Voss J (1987) Biologie et comportement des Labridés européens (Labres, Crénilabres, Rouquiers, Vieilles et Girelles). Rev Fr Aquariol Herpétol 14:1-80

Overstreet RM (1988) Aquatıc pollution problems; southeastern US coasts: histopathological indicators. Aquat Toxicol 11:213-239

Overstreet RM, Howse HD (1977) Some parasites and diseases of estuarine fishes in polluted habitats of Missis- 
sippi. Ann NY Acad Sci 298:427-462

Prevot G (1965) Complément à la connaissance de Proctoeces maculatus (Looss 1901) Odhner 1911 [syn. P. erythraeus Odhner 1911 et $P$ subtenuis (Linton 1907) Hanson 1950] (Trematoda, Digenea, Fellodistomatidae). Bull Soc Zool Fr 90:175-179

Sherrer B (1984) Biostatistique. Morin G (ed) Boucherville, Québec, pi-xix + 1-850

Sicldall R, des Clers S (1994) Effect of sewage sludge on the miracidium and cercaria of Zoogonoides viviparus (Trematoda: Digenea). Helminthologia 31:143-153

Sulgostowska T (1988) Changes in the parasite fauna of the flounder Platichthys flesus dependant on the degree of pollution of the south-western Baltic Sea. Wiad Parazytol 34:591-594

Valls SR, Artaud J, Amade P. Vicente N, Piovetti L (1994a) Determination of caulerpenyne, a loxin from the green

This article was submitted to the editor alga Caulerpá taxifolia (Caulerpaceae). J Chromatogr 663: $114-118$

Valls SR, Mesguiche V, Lemme R, Plovetti L, Amade P, Artaud J, Pesando D. Vicente N (1994b) Dosage de la caulerpényne, toxine de l'algue verte Caulerpa taxifolia. Cryptogam Algol 15:14

Valtonen ET, Koskivaara M, Brummer-Korvenkontio H (1987) Parasites of fishes in central Finland in relation to environmental stress. Biol Res Rep [ niv Jyvaskyla 10:129-130

Verlaque M. Fritayre P (1994) Modifications des communautés algales méditerranéennes en présence de l'algue envahissante Caulerpa taxifolia (Vahl) C. Agardh. Oceanol Acta 17:659-672

Villèle de X, Verlaque M (1995) Changes and degradation in a Posidonia oceanica bed invaded by the introduced tropical alga Caulerpa taxifolia in the north western Mediterranean. Bot Mar 38:79-87

Manuscript received: March 14, 1997

Revised version accepted: May 30, 1997 